BNL- 65453

Informal Report

\title{
Co-Processing Coal and Natural Gas by the Hynol Process for Enhanced Methanol Production and Reduced $\mathrm{CO}_{2}$ Emissions
}

Prepared by:

Meyer Steinberg

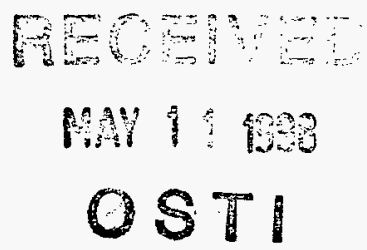

June 19, 1997

Engineering Technology Division

DEPARTMENT OF ADVANCED TECHNOLOGY, BROOKHAVEN NATIONAL LABORATORY UPTON, NEW YORK 11973

[DTC QUALTTY INEPECTED 1

\author{
Prepared for the U.S. Department of Energy \\ Washington, DC \\ Contract No. DE-AC02-98CH10886
}




\section{Disclaimer}

This report was prepared as an account of work sponsored by an agency of the United States Government. Neither the United States Government nor any agency thereof, nor any of their employees, or any of their contractors, subcontractors, or their employees, makes any warrantee, expressed or implied, or assumes any legal liabilities or responsibility for the accuracy, completeness, or usefulness of an information, apparatus, product, or process disclosed, or represents that its use would not infringe privately owned rights. Reference herein to any specific commercial product, process or service by trade name, trademark, manufacturer, or otherwise, does not necessarily constitute or imply its endorsement, recommendation, of favoring by the United States Government or any agency, contractor, or subcontractor thereof. The views and opinions of authors expressed herein do not necessarily state or reflect those of the United States Government or any agency contractor or subcontractor thereof. 


\title{
Co-Processing Coal and Natural Gas by the Hynol Process for Enhanced Methanol Production and Reduced $\mathrm{CO}_{2}$ Emissions
}

\author{
Prepared by \\ Meyer Steinberg \\ Brookhaven National Laboratory \\ Engineering Technology Division \\ Department of Advanced Technology \\ Upton, New York 11973
}

June 19, 1997

Prepared for

U.S. Department of Energy

Washinton, DC

DISTRIBUTION OF thIS DOCIMENT is UNLIMITED 


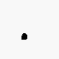

. 


\begin{abstract}
The Hynol Process for conversion of coal and natural gas to methanol as a liquid fuel consists of three consecutive unit operations (1) hydrogasification of coal, (2) steam reforming of the methane formed and added natural gas feedstock, and (3) catalytic methanol synthesis. The Hynol Process is a total recycle process. Using a process simulation computer program, mass and energy balances and yields and efficiency data have been obtained for a range of natural gas to coal feedstock ratios. Although the methanol yield increases with natural gas to coal feed ratio, the cost of feedstock per unit methanol is insensitive over a wide range of feedstock ratios. The Hynol Process produces a $13 \%$ increase in methanol yield compared to the equivalent of two separate conventional coal gasification and natural gas reforming plants. The $\mathrm{CO}_{2}$ emissions are reduced by $22 \%$ for the Hynol plant compared to the conventional processes with greater $\mathrm{CO}_{2}$ reductions at lower gas to coal feedstock ratios. A preliminary cost estimate for a 10,000 Tons/Day Hynol methanol plant indicates a lower production cost than the current cost of methanol by the conventional natural gas reforming plant. The lower unit energy cost for coal is beneficial in reducing the methanol cost in the Hynol Process.
\end{abstract}




\section{CONTENTS}

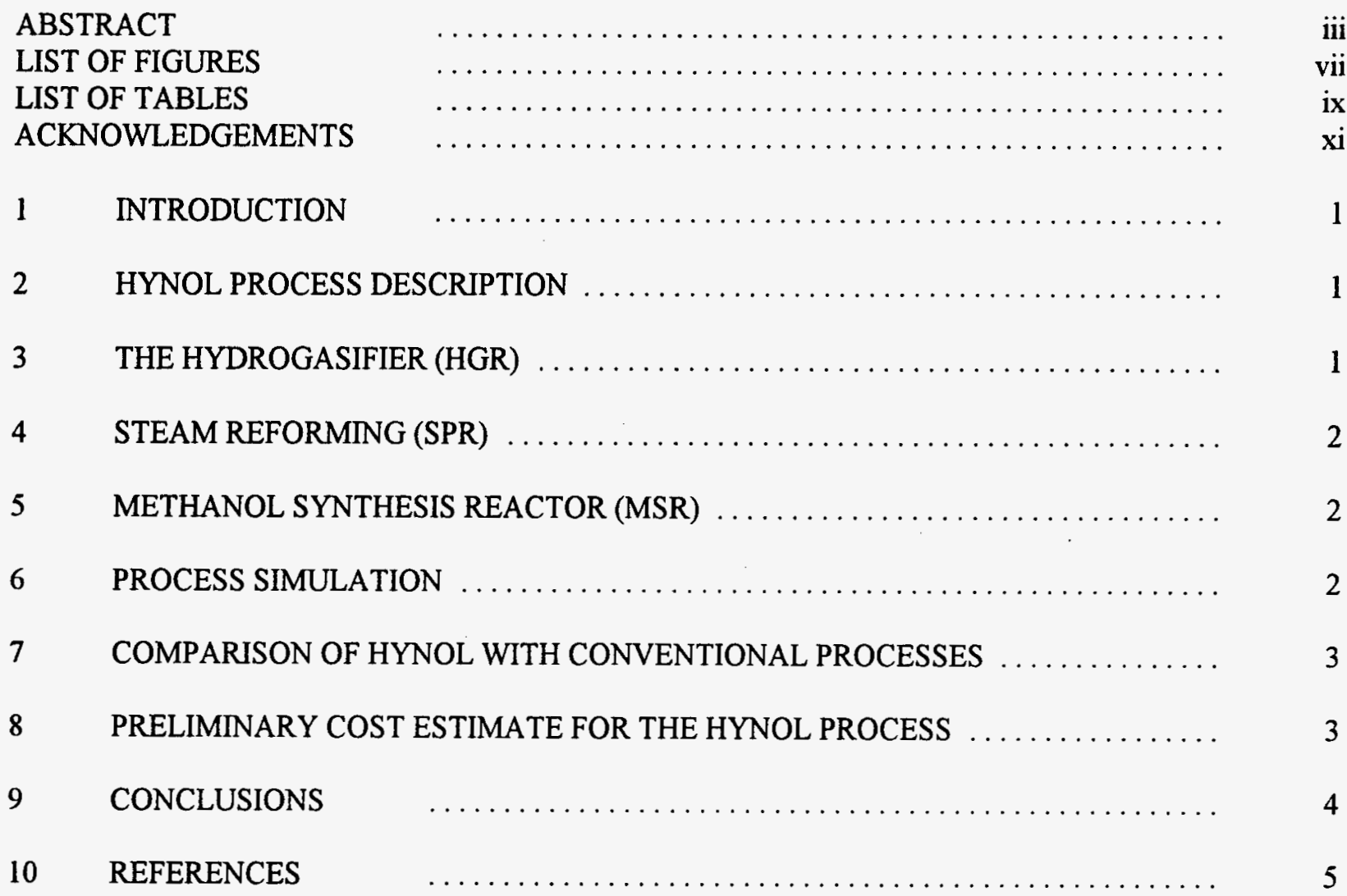




\section{LIST OF FIGURES}

Page

Figure 1

The Hynol Process

A-6 


\section{+}




\section{LIST OF TABLES}

Table $1 \quad$ Feedstock and Gas Feed Conditions to Each Reactor $\ldots \ldots \ldots \ldots \ldots \ldots \ldots$ A-1

Table 2 Methanol Yields, Efficiency and $\mathrm{CO}_{2}$ Emissions $\ldots \ldots \ldots \ldots \ldots \ldots \ldots \ldots \ldots \ldots \ldots$

Table 3 Feedstock Cost as a Function of Natural Gas to Coal Ratio $\ldots \ldots \ldots \ldots$ A-3

Table 4 Comparing Coal/Natural Gas (NG) Hynol Process with Conventional Coal Gasification and Natural Gas Reforming Processes for Methanol Production .... . A-4

Table 5 Preliminary Cost Estimate for Methanol Production by Hynol Process ........ A-5 


\section{ACKNOWLEDGEMENTS}

Appreciation goes to Mr. Yuanji Dong of the Acurex Co. in Research Triange Park, North Carolina, for running the process simulation computer model in obtaining the mass and energy balances for the Hynol Process. 


\section{INTRODUCTION}

The Hynol Process was originally conceived to process biomass (wood and agricultural products) for the production of methanol with reduced $\mathrm{CO}_{2}$ emission ${ }^{[1,2]}$. Effort has also been made to apply the process to municipal solid waste (MSW) feedstock ${ }^{[3]}$. The Hynol Process in general can be applied to the use of any condensed carbonaceous material as feedstock. A basic feature of the Hynol Process is that natural gas is used as a co-feedstock with the condensed carbonaceous feedstock to produce a higher yield of methanol per unit feedstock than is obtained when using either co-feedstock alone in the conventional process for producing methanol. The reason for the improved yield is that the condensed feedstock has a deficiency of hydrogen compared to carbon, while natural gas has an excess of hydrogen compared to carbon. Thus, the co-feedstock of condensed carbonaceous material with natural gas yields the closest approach to optimizing the hydrogen to carbon content for producing the product methanol. Another feature of the Hynol Process is that it is a complete recycle system maximizing the mass and energy balance. In this paper, we apply the Hynol Process to the co-processing of coal with natural gas.

\section{HYNOL PROCESS DESCRIPTION}

The Hynol Process consists of three process reaction steps (1) the hydrogasification of the condensed carbonaceous material (wood, coal, etc.) with recycle hydrogen-rich gas to produce a methane-rich gas, (2) the steam reforming of the methane-rich gas together with the addition of the co-feedstock methane to produce carbon monoxide and hydrogen. The excess gas from the methanol synthesis reactor which is rich in hydrogen is recycled to the hydrogasifier at the head end of the process. Figure 1 gives a generalized flow diagram for the Hynol Process. The process chemistry for each unit is given in the following paragraphs.

\section{THE HYDROGASIFIER (HGR)}

The main reaction taking place in the HGR is between the condensed carbonaceous carbon and the hydrogen in the recycle gas to produce methane:

$$
\mathrm{C}+2 \mathrm{H}_{2}=\mathrm{CH}_{4}
$$

This is an exothermic reaction generating $18 \mathrm{Kcal} / \mathrm{mol}$ of $\mathrm{CH}_{4}$ produced. However, the wood (stoichiometrically $\left.\mathrm{CH}_{1.4} \mathrm{O}_{0.6}\right)$ or coal $\left(\mathrm{CH}_{0.8} \mathrm{O}_{0.1}\right)$ contains oxygen so that two additional reactions must be taken into account:

$$
\mathrm{C}+\mathrm{H}_{2} \mathrm{O}=\mathrm{CO}+\mathrm{H}_{2}
$$

which is endothermic absorbing about $42 \mathrm{Kcal} / \mathrm{mol} \mathrm{C}$ and

$$
\mathrm{CO}_{2}+\mathrm{H}_{2}=\mathrm{CO}+\mathrm{H}_{2} \mathrm{O}
$$

which is energetically about neutral.

The conditions favoring high hydrogasification of the carbonaceous material is higher pressure, 30 to $50 \mathrm{~atm}$, and higher temperature, $800-900^{\circ} \mathrm{C}$. A suitable design for the HGR is a fluidized bed reactor with either sand or the ash from the condensed carbonaceous material to act as a fluidizing medium. The main feature of the HGR is that it is designed so that it is self sufficient in energy not requiring any outside energy to maintain the reaction conditions. The hydrogasification of coal has been studied extensively in the past ${ }^{[4]}$. Unconverted char from the HGR can be used as a fuel or sequestered. In the case of biomass or coal, impurities such as sulfur may be gasified in the HGR so that a gas cleanup step is required. The sulfur can be removed as calcium sulfide with limestone. 


$$
\mathrm{CaCO}_{3}+\mathrm{H}_{2} \mathrm{~S}=\mathrm{CaS}+\mathrm{CO}_{2}+\mathrm{H}_{2} \mathrm{O}
$$

\section{STEAM REFORMING (SPR)}

The steam reformer, also called the steam pyrolysis reactor (SPR), combines the methane with steam to produce carbon monoxide and hydrogen. Any $\mathrm{CO}_{2}$ present and hydrogen also produces carbon monoxide.

$$
\begin{aligned}
& \mathrm{CH}_{4}+\mathrm{H}_{2} \mathrm{O}=\mathrm{CO}+3 \mathrm{H}_{2} \\
& \mathrm{CO}_{2}+\mathrm{H}_{2}=\mathrm{CO}+\mathrm{H}_{2} \mathrm{O}
\end{aligned}
$$

The first reaction is highly endothermic requiring about $60 \mathrm{Kcal} / \mathrm{mol}$ of $\mathrm{CO}$ produced and the second reaction is about neutral. There is much experience operating steam reformers ${ }^{[5]}$. The reactor design is usually a nickel catalyst packed tubular reactor which usually operates in the range of 30 to $50 \mathrm{~atm}$ and about $1000^{\circ} \mathrm{C}$. The co-feedstock methane is added to the HGR gas together with sufficient steam to produce the $\mathrm{CO}$ and $\mathrm{H}_{2}$. The heat required for the endothermic reaction is supplied by combustion of methane with air in a furnace surrounding the catalyst packed tubular reactor. Heat exchangers are used to maintain an energy balance and produce steam for the process.

\section{METHANOL SYNTHESIS REACTOR (MSR)}

After cooling the gases from the SPR essentially containing $\mathrm{H}_{2}$ and $\mathrm{CO}$ in ratios exceeding 3 is fed to a conventional catalytic methanol synthesis reactor using a copper based low pressure catalyst ${ }^{[6]}$. The two reactions taking place in the MSR leading to methanol are as follows:

$$
\begin{gathered}
\mathrm{CO}+2 \mathrm{H}_{2}=\mathrm{CH}_{3} \mathrm{OH} \\
\mathrm{CO}_{2}+3 \mathrm{H}_{2}=\mathrm{CH}_{3} \mathrm{OH}+\mathrm{H}_{2} \mathrm{O}
\end{gathered}
$$

Both reactions are exothermic by about $31 \mathrm{Kcal} / \mathrm{mol}$ methanol. The reactor must be cooled and the heat recovered as process steam may be used in the process to make up heat balances. A recycle ratio of 5 to $l$ is used around the MSR to obtain high methanol conversions. The condensed methanol-water mixture is finally fractionated to produce fuel and chemical grade methanol. None of the gas is wasted. All the hydrogen-rich gas from the MSR is recycled to the HGR.

\section{PROCESS SIMULATION}

A process simulation computer model was used to obtain mass and energy balances and to perform a parametric analysis. The computer program is based on an equilibrium model. Table 1 gives the elemental analysis of the bituminous coal used and the typical composition and flow rate of the gas feed to each of the major reactors as shown in Figure 1. Table 2 gives the results of the yields, efficiency and $\mathrm{CO}_{2}$ emissions as a function of natural gas to coal feed ratio.

The conclusions drawn from the process simulations are as follows:

1. As the total natural gas to co-feedstock ratio increases, the methanol yield per unit coal increases significantly, while the methanol to total natural gas feedstock decreases only slightly.

2. The temperature of the gas to the HGR necessary to make the HGR energy self-sufficient decreases with increasing natural gas to coal feed ratio. 
3. The carbon conversion (coal carbon to gasified carbon) in the HGR increases with natural gas to coal feed ratio.

4. Interestingly enough, the $\mathrm{CO}_{2}$ emissions per unit energy remains about the same over the range of feedstock ratios. The $\mathrm{CO}_{2}$ emission includes the $\mathrm{CO}_{2}$ emitted in the process and the $\mathrm{CO}_{2}$ from the combustion of the methanol product.

The natural gas to coal feed ratio choice depends on the economics of the process. A first order estimate mode in Table 3 assuming plant capital cost for a fixed methanol production rate is approximately the same for the range of feedstock ratios shown in Table 2, indicates a rather constant raw material cost per unit methanol based on current U.S. coal costs in the range of $\$ 20$ to $\$ 30 /$ ton and current U.S. natural gas costs in the range of $\$ 2.00$ to $\$ 2.50 / \mathrm{MM}$ BTU. The reason for this is that the feedstock cost, under these conditions, is mainly dominated by the natural gas cost. Because of this cost insensitivity, the choice of feedstock ratio then becomes dependent on the availability of the feedstock materials. A feedstock ratio choice can also be based on a reasonably achievable carbon-conversion in the HGR. From experience, we assume the HGR carbon conversion efficiency can be obtained up to about $81.5 \%$ resulting from a feedstock ratio of 1.59 .

\section{COMPARISON OF HYNOL WITH CONVENTIONAL PROCESSES}

The conventional process for methanol production is based on the steam reforming of natural gas. The process consists of a steam reformer, shift reactor and methanol synthesis reactor ${ }^{[7]}$. When coal is used as a feedstock, the coal is gasified with steam and oxygen in a gasifier. The resulting gas is shifted with steam to adjust the $\mathrm{CO} / \mathrm{H}_{2}$ ratio and is then fed to a methanol synthesis reactor ${ }^{[7]}$. Table 4 compares the Hynol Process using co-feedstocks of coal and natural gas with the conventional coal gasification and natural gas reforming plant each operating separately with the same quantities of feedstock as in the Hynol plant when the feedstock ratio is 1.59 . It can be seen that the Hynol plant products 6 times more methanol per unit of coal than the conventional coal gasification plant and 1.4 times more than the natural gas reforming plant. Thus, the Hynol plant products $13 \%$ more methanol than the sum of the two conventional coal gasification and methanol reforming plants. The $\mathrm{CO}_{2}$ emission is even more significant in that the Hynol plant products $22 \%$ less $\mathrm{CO}_{2}$ emissions than the two conventional plants. The $\mathrm{CO}_{2}$ emissions become less by $35 \%$ when the NG/coal decreases to 0.84 . The $\mathrm{CO}_{2}$ emission takes into account the $\mathrm{CO}_{2}$ emitted by the methanol production plants and that generated by the combustion of methanol. It should be noted that methanol used as fuel in internal combustion automotive engines can be $30 \%$ more efficient than gasoline driven engines thus further reducing $\mathrm{CO}_{2}$ emissions ${ }^{[9]}$. An even greater reduction in $\mathrm{CO}_{2}$ emission by a factor of at least 2.5 can be achieved when using methanol in a direct fuel cell for automotive power ${ }^{[10]}$.

\section{PRELIMINARY COST ESTIMATE FOR THE HYNOL PROCESS}

A preliminary cost estimate is made for the production of methanol from a coal/natural gas Hynol plant with the following economic assumptions.

1. Assume a world size plant producing $10,000 \mathrm{~T} / \mathrm{D}$ methanol.

2. Capital cost estimated at $\$ 800$ million based on estimates of a similar Hynol plant with wood as feedstock ${ }^{[2]}$. 
3. Plant factor of $90 \%$, operating 328.5 days/yr.

4. Cost of coal $=\$ 25 /$ ton $=\$ 27.75 /$ ton $M F$ coal.

5. Cost of $\mathrm{NG}=\$ 2.50 / \mathrm{MSCF}=\$ 118.80 /$ ton methane.

These feedstock costs reflect current U.S. conditions.

6. $O$ and $M$ cost based on percentage of capital investment; $1 \%$ for labor, $2 \%$ for maintenance, $1 \%$ for power and $2 \%$ for catalysts and miscellaneous for a total $\mathrm{O}$ and $\mathrm{M}$ charge of $6 \%$ on capital investment.

7. Capital charges based on a $80 / 20$ debt/equity ratio and includes depreciation, return on investment (ROI), interest charges of debt and taxes; this amounts to a total of $19 \%$ on capital investment.

The results of the preliminary cost estimate is shown in Table 5. The unit production cost which includes ROI, turns out to be $\$ 124 /$ ton or $\$ 0.41 /$ gal of methanol. The traditional selling price and production cost of methanol for a conventional natural gas reforming plant has been $\$ 0.45 /$ gallon. Because of the mandatory requirement for the addition of MTBE to gasoline which is produced from methanol, the demand has increased the selling price last year to almost $\$ 2 /$ gallon. It has since dropped to the present level of about $\$ 0.57 /$ gallon ${ }^{[8]}$. Thus, the estimated cost of methanol for the coal/natural gas co-feedstock Hynol plant at $\$ 0.41 /$ gas is highly competitive. It should be noted that even if the capital investment has been under-estimated by $20 \%$, the cost of methanol would only increase by $10 \%$ to $\$ 0.45 /$ gas which is still competitive with the conventional process. Besides the improved yield of methanol compared to the conventional processes mentioned earlier, the cost of coal which makes up about $25 \%$ of the feedstock energy cost of the plant is less than half the cost of natural gas on a unit energy basis. The result is a lower overall unit feedstock cost and, as shown earlier, this factor appears to be insensitive to the natural gas/coal feedstock ratio.

\section{CONCLUSIONS}

The Hynol Process operating with coal and natural gas as feedstocks yields at least $13 \%$ more methanol than the equivalent of two separate conventional steam-oxygen coal gasification and natural gas-steam reforming plants. The $\mathrm{CO}_{2}$ emissions become even less with lower gas to coal feedstock ratios. Use of methanol fuel cells for automotive power could significantly decrease $\mathrm{CO}_{2}$ emission compared to convention IC engines. A preliminary cost estimate for a 10,000 T/D Hynol methanol plant indicates a production and selling price cost lower than that for current conventional natural gas steam reforming plant. The Hynol cost for methanol appears to be insensitive to the natural gas to coal feedstock ratio over a wide range. 


\section{REFERENCES}

1. M. Steinberg and Y. Dong, "Process and Gyroratios for the Production of Methanol from Condensed Carbonaceous Material," U.S. Pat. RE 35,377 (November 12, 1996).

2. M. Steinberg and Y. Dong, "Hynol-An Economic Process for Methanol Production from Biomass and Natural Gas with Reduced $\mathrm{CO}_{2}$ Emission," BNL-49733, Brookhaven National Laboratory, Upton, New York (October 1993).

3. REM Capital Corp., "Waste to Methanol Project Summary," Internal Report (September 3, 1994).

4. M. Steinberg, "The Flash Hydropyrolysis and Methanolysis of Coal with Hydrogen and Methane," Int. J. Hydrogen Energy 12, No. 4, pp. 251-66 (1987).

5. D.E. Redler and M.V. Twigg, "Steam Reforming" in Catalyst Handbook, 2nd Ed., M.V. Twigg ed., Wolfe Publishing Co., London (1989).

6. S. Lee, Methanol Synthesis Technology, CRC Press, Inc., Boca Raton, Florida (1990).

7. C.E. Wyman, R.L. Bain, N.D. Hinman and D.J. Stevens, "Ethanol and Methanol from Celluosic Biomass," in Renewable Energy Sources for Fuels and Electricity, Ed. T.B. Johanssen et al., p. 914, Island Press, Washington, D.D. (1992).

8. Hart's Oxy-Fuel News, Vol. VIII, No. 47 (December 2, 1996).

9. Motor Vehicle Emission Laboratory (MVEL), "An Analysis of the Economic and Environmental Effects of Methanol as an Automotive Fuel," EPA Report No. 0730, Ann Arbor, Michigan (September 1989).

10. World Car Conference '96, Bourns College Engineering Center for Environmental Research and Technology, University of California, Riverside, California (January 21-February 4, 1996). 

Table 1

Feedstock and Gas Feed Conditions to Each Reactor

Bituminous coal feed to HGR - elemental analysis, wt \% moisture free MF

(coal feed contains $10 \%$ moisture)

$\begin{array}{lll}\mathrm{C} & - & 73.33 \\ \mathrm{H} & - & 4.97 \\ \mathrm{O} & - & 7.90 \\ \mathrm{Ash} & - & 9.13 \\ \mathrm{~S} & - & 3.12 \\ \mathrm{~N} & - & 1.55\end{array}$

Gas flow rate (Kmol/h) and composition (Vol. \%) based on $100 \mathrm{Kg} / \mathrm{hr}$ coal for $100 \mathrm{Kg} / \mathrm{hr} \mathrm{NG}$ addition to SPR and 39.3 NG to Reformer Furnace. Methanol Production $=345 \mathrm{Kg} / 100 \mathrm{Kg}$ MF Coal.

\begin{tabular}{cccc}
\multicolumn{1}{c}{ Feed to } & 1-HGR & 2-SPR & 3-MSR \\
\hline Press, atm & 30.00 & 25.00 & 40.00 \\
Temp. ${ }^{\circ} \mathrm{C}$ & 552.00 & 400.00 & 100.00 \\
Rate Kmol/hr & 16.93 & 48.16 & 53.70 \\
Gas Comp. Vol. \% & & & \\
$\mathrm{CO}$ & 3.53 & 2.80 & 18.19 \\
$\mathrm{CO}_{2}$ & 1.61 & 0.95 & 4.31 \\
$\mathrm{CH}_{4}$ & 3.39 & 22.86 & 1.36 \\
$\mathrm{H}_{2} \mathrm{O}$ & 13.18 & 57.01 & 0.55 \\
$\mathrm{H}_{2}$ & 76.15 & 15.84 & 75.10 \\
$\mathrm{~N}_{2}$ & 1.19 & 0.54 & 0.48 \\
$\mathrm{MeOH}$ & 0.94 & 0.00 & 0.00 \\
\hline
\end{tabular}

A-1 
Table 2

Methanol Yields, Efficiency and $\mathrm{CO}_{2}$ Emissions

Bituminous Coal Feedstock $100 \mathrm{Kg} / \mathrm{hr} \mathrm{MF}$

$\mathrm{NG}=$ natural gas

\begin{tabular}{lcccc}
\hline NG Feedstock, Kg & 50 & 75 & 100 & 125 \\
NG Fuel for Reforming, KG & 33.5 & 46.5 & 59.3 & 72.2 \\
Total NG/MF Coal Ratio & 0.84 & 1.22 & 1.59 & 1.97 \\
C Conversion in HGR, \% & 57.3 & 69.7 & 81.5 & 93.4 \\
Thermal Efficiency, \% & 59 & 63 & 65 & 67 \\
& & & & \\
Temp. of Gas to HGR, ${ }^{\circ} \mathrm{C}$ & 899 & 693 & 552 & 458 \\
& & & & 415 \\
$\mathrm{Methanol} \mathrm{Product,} \mathrm{Kg}_{\text {MeOH/MF Coal Kg/Kg }}$ & 204 & 275 & 345 & 4.15 \\
$\quad$ MeOH/Total NG Kg/Kg & 2.04 & 2.75 & 3.45 & 2.10 \\
$\mathrm{CO}_{2}$ Emissions Lbs/MMBTU & 2.44 & 2.26 & 2.17 & 194 \\
\hline
\end{tabular}


Table 3

Feedstock Cost as a Function of Natural Gas to Coal Ratio

Natural Gas Cost $-\$ 2.50 / \mathrm{MMBTU}=\$ 118.80 /$ ton Methane

Coal Cost $=\$ 25 /$ ton $(\$ 27.75 /$ ton MF)

\begin{tabular}{lcrrr}
\hline Feedstock NG/MF Coal Ratio, Tons/Ton & 0.84 & 1.22 & 1.59 & 1.97 \\
Methanol Produced & & & & \\
MeOH/MF Coal Ratio, Tons/ton & 2.04 & 2.75 & 3.45 & 4.15 \\
MeOH/NG Ratio, Tons/ton & 2.44 & 2.26 & 2.17 & 2.10 \\
& & & & \\
Feedstock Cost & & & & \\
MF Coal - \$/ton MeOH & 13.60 & 10.10 & 8.05 & 6.69 \\
NG - \$/ton MeOH & 48.67 & 52.54 & 54.72 & 56.55 \\
& & & & 62.77 \\
\hline
\end{tabular}


Table 4

Comparing Coal/Natural Gas (NG) Hynol Process with Conventional Coal Gasification and Natural Gas Reforming Processes for Methanol Production

\begin{tabular}{cccc}
\multicolumn{1}{c}{ Factor } & $\begin{array}{c}\text { Hynol } \\
\text { Process }\end{array}$ & $\begin{array}{c}\text { Conventional } \\
\text { Coal } \\
\text { Gasification }\end{array}$ & $\begin{array}{c}\text { Processes NG } \\
\text { Reforming }\end{array}$ \\
\hline $\begin{array}{c}\text { Feedstock } \\
\text { MF Coal, Kg } \\
\text { Total NG, Kg }\end{array}$ & 100.00 & 100.00 &.-- \\
Oxygen, Kg & 159.3 & --- & 159.3 \\
Thermal Eff., \% & --- & 80.0 & -- \\
Carbon Conversion, \% & 65.1 & 50.8 & 64.0 \\
Methanol Yield & & & 78.0 \\
MeOH/Coal & 67.1 & 25.1 & \\
MeOH/NG & & & --
\end{tabular}

$\mathrm{MeOH}$ Product, $\mathrm{Kg}$

\begin{tabular}{|c|c|c|c|c|}
\hline & & 57 & \multirow[b]{2}{*}{306} & \multirow[t]{2}{*}{249} \\
\hline Total $\mathrm{MeOH}, \mathrm{Kg}$ & 345 & & & \\
\hline $\begin{array}{l}\% \mathrm{MeOH} \text { Hynol Increase } \\
\text { Over. Conv. Process }\end{array}$ & $13 \%$ & & & \\
\hline \multicolumn{5}{|l|}{ hission } \\
\hline & & 550 & \multirow{3}{*}{249} & 180 \\
\hline Lbs $\mathrm{CO}_{2} / \mathrm{MMBTU}$ & 194 & & & \\
\hline $\begin{array}{l}\% \mathrm{CO}_{2} \text { Reduction by } \\
\text { Hynol Compared to } \\
\text { Conv. Processes }\end{array}$ & $22 \%$ & & & \\
\hline
\end{tabular}


Table 5

Preliminary Cost Estimate for Methanol Production by Hynol Process

$$
\begin{gathered}
\text { Natural Gas/MF Coal Feedstock Ratio }=1.59 \\
\text { MeOH Plant Capacity }=10,000 \mathrm{~T} / \mathrm{D} \\
\text { Capital Investment }=\$ 800 \times 10^{6} \\
\text { Plant Factor }=90 \%(328.5 \mathrm{p}, \text { Days } / \mathrm{yr})
\end{gathered}
$$

\begin{tabular}{|c|c|c|c|c|}
\hline Production Cost & & & & \$ MM/Day \\
\hline Coal $=2900 \times \$ 27.75 /$ ton & & & $=$ & 0.08 \\
\hline Natural Gas $=4608 \times \$ 118.75$ & & & $=$ & 0.55 \\
\hline$O$ and $M=$ & $0.06 \mathrm{x}$ & $\frac{\$ 800 \mathrm{MM}}{328.5}$ & $=$ & 0.15 \\
\hline Total Capital Charge $=$ & $0.19 x$ & $\frac{\$ 800 \mathrm{MM}}{328.5}$ & $=$ & 0.46 \\
\hline Total Production Cost & & & $=$ & 1.24 \\
\hline Unit Production Cost & & & $=$ & $\$ 124 /$ ton \\
\hline Selling Price & & & $=\frac{124}{303}$ & $\$ 0.41 / \mathrm{gal}$ \\
\hline
\end{tabular}




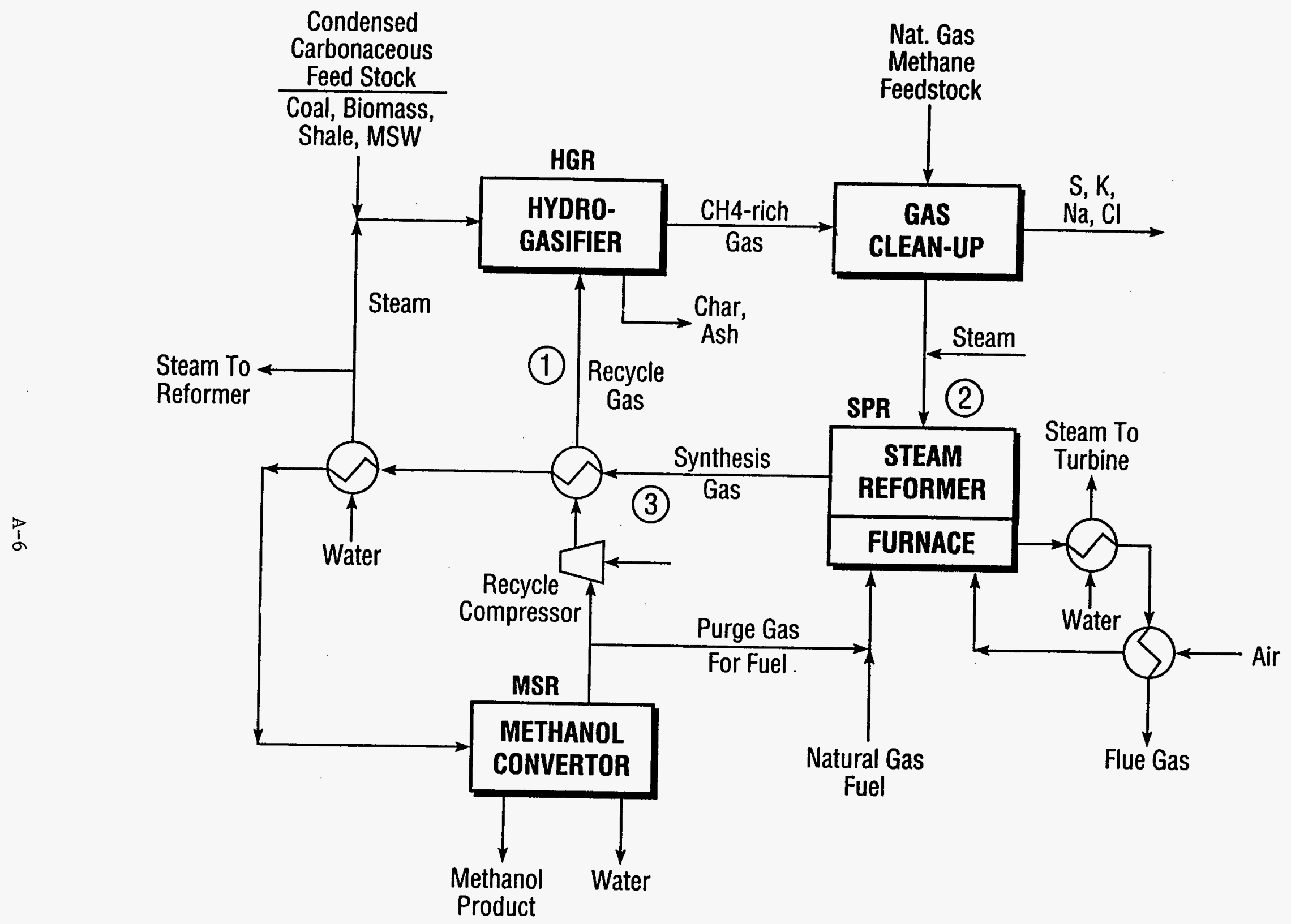

THE HYNOL PROCESS

Figure 1 
M98004923

Report Number (14) $3 \mathrm{NC}-65453$

Publ. Date (11) 9970619

Sponsor Code (18) $\frac{D Q \varepsilon / F q, X F}{U C-125, D O E / E R}$

DOE 